\title{
DUA KOTA SATU ATAP : KEBIJAKAN PEMUKIMAN PENDUDUK KOTA JAKARTA DAN DEPOK (1970-an Hingga Akhir 1990-an)
}

\author{
Saring \\ Program Studi Pendidikan Sejarah, \\ Fakultas Ilmu Pendidikan dan Pengetahuan Sosial, Universitas Indraprasta PGRI \\ Email: Saring.ariyanto2009@gmail.com
}

Diterima: Oktober; Disetujui: April; dipublikasikan: 28 April 2019

\begin{abstract}
Jakarta as the center of administrative and governmental activities, as well as the center of national economic activities, finally made this city a prima donna for urbanites to come and try their luck in Jakarta. The shadow of success and hope for improving economic conditions from the area of origin becomes a kind of hope that always lives in the minds of the urbanites. In reality, the presence of urban people has become a new problem faced by the Special Capital Region of Jakarta, the presence of urbanites who generally do not have decent skills, and provision of administration (as citizens) is a problem that is quite significant for the development of the city of Jakarta. The existence of urbanites who always come and increase in number on the one hand, and on the other hand the existence of space for residential areas in the increasingly depleted city of Jakarta, making the issue of the needs of the trustees and decent housing is quite difficult to obtain. In order to overcome the problem of fulfilling residential needs for the people of Jakarta, the DKI Jakarta government, through the power possessed by the central government, made Depok city an alternative area to divide the heavy burden of Jakarta in terms of population issues (residential settlements).
\end{abstract}

Keywords: Settlement, Jakarta, Depok

\begin{abstract}
ABSTRAK
Jakarta sebagai pusat dari kegiatan administrasi dan pemerintahan, serta sentra kegiatan ekonomi nasional, akhirnya menjadikan kota ini sebagai primadona bagi kaum urban untuk datang dan mengadu nasib di Jakarta. Bayang-bayang kesuksesan dan harapan untuk memperbaiki keadaan ekonomi dari wilayah asal, menjadi semacam harapan yang selalu hidup di dalam fikiran para kaum urban. Dalam realitasnya kehadiran kaum urban justru menjadi persoalan baru yang dihadapi oleh pemerintah Daerah Khusus Ibu Kota Jakarta, kehadiran kaum urban yang umumnya tidak memiliki keterampilan yang layak, serta bekal administrasi (sebagai warga negara) menjadi persoalan yang cukup siginifikan bagi perkembangan kota Jakarta. Keberadaan para kaum urban yang selalu datang dan meningkat jumlahnya disatu sisi, dan disisi lain keberadaan ruang untuk wilayah pemukiman di kota Jakarta yang semakin menipis, membuat persoalan mengenai kebutuhan pemikiman dan rumah tinggal yang layak cukup sulit untuk didapatkan. Guna mengatasi persoalan pemenuhan kebutuhan tempat tinggal bagi masyarakat kota Jakarta, pemerintah DKI Jakarta, melalui kemampuan (power) yang dimiliki oleh pemerintah pusat, menjadikan kota Depok sebagai wilayah alternatif untuk membagi beban berat kota Jakarta dalam hal persoalan kependudukan (pemukiman penduduk).
\end{abstract}

Kata kunci: Pemukiman, Jakarta, Depok 


\section{PENDAHULUAN}

Pemukiman penduduk merupakan salah satu isu sentral dewasa ini, khususnya bagi kotakota besar di Indonesia. Jakarta sebagai salah satu kota besar di Indonesia saat ini (pusat pemerintahan dan perputaran ekonomi nasional), menghadapi kendala yang cukup pelik dalam konteks pemanfaatan ruang bagi kebutuhan pemukiman penduduk. Persoalan pemanfataan ruang di kota Jakarta bagi kebutuhan pemukiman penduduk, mulai dirasakan sejak pelaksanaan kebijakan pembangunan nasional pada masa pemerintahan Presiden Soeharto. Jakarta sebagai kota pusat pemerintahan dan ekonomi sejak akhir 1960-an, mulai melaksanakan program pembangunan infrastruktur dalam bentuk pengadaan gedung-gedung pemerintahan dan gedung perkantoran untuk pusat kegiatan ekonomi dan bisnis. Pembangunan infrastruktur, baik dalam bentuk bangunan dan gedung-gedung (pusat pemerintahan dan kegiatan ekonomis), maupun pembangunan sarana-prasarana pendukung, seperti moda transportasi, sarana kesehatan, pendidikan dan peribadatan (Sulistiyani, 2002: 327-328).

Berbekal keberadaan infrastruktur sebagai penunjang kegiatan serta aktivitas sosialekonomis keseharian di kota Jakarta, kehadiran para pendatang yang masuk ke dalam kota Jakarta setiap waktu semakin bertambah. Kehadiran kaum urban di kota Jakarta, baik dalam segala bentuk motif memberikan implikasi yang cukup besar bagi perkembangan kota Jakarta. Keberadaan sarana pemukiman bagi tempat tinggal para kaum urban menjadi satu hal yang cukup mendesak untuk diselesaikan. Peningkatan jumlah penduduk secara temporal yang terus menerus bertambah di setiap waktunya, memaksa pemerintah kota Jakarta untuk membuka dan memanfaatkan space (ruang) yang ada, baik di dalam kota Jakarta, maupun daerah perbatasan dengan wilayah luar Jakarta (seperti Depok, Tanggerang Selatan, dan Bekasi) untuk menjadi wilayah pemukiman baru bagi orang-orang (urban) yang bekerja di Jakarta.

Depok adalah salah satu wilayah yang kemudian dipilih oleh pemerintah pusat untuk menyelesaikan kebutuhan pemukiman penduduk masyarakat urban Jakarta. Depok sebagai sebuah kota yang berada di bawah pemerintahan propinsi Jawa Barat (hingga 1990-an berada di bawah naungan Kabupaten Bogor), merupakan wilayah yang telah ditetapkan sebagai wilayah altrenatif untuk pemecahan persoalan kebutuhan pemukiman penduduk kota Jakarta. Rencana kota Depok sebagai alternatif pemecahan persoalan pemukiman penduduk kota Jakarta, telah direncanakan sejak pemerintahan Gubernur Jakarta Ali Sadikin. Dalam laporan Gubernur Ali Sadikin (Gita Jaya), disebutkan bahwa untuk mengurangi beban dan permasalahan kependudukan di kota Jakarta (berkaitan dengan pemukiman penduduk), pemerintah kota Jakarta berencana untuk membagi persoalan pemukiman penduduk, dengan membuka wilayah pemukiman baru di kota Depok, sebagai wilayah terdekat Jakarta dengan propinsi Jawa Barat.

Sejak 1974 (pada masa kepemimpinan kedua Gubernur Ali Sadikin di Jakarta) pemerintah pusat memberikan jalan untuk membuka wilayah pemukiman baru di kota Depok (Gita Jaya, 1977: 68). Pembangunan pemukiman baru tersebut dilakukan secara besar-besaran, dengan konsep pemukiman yang diberikan nama Perumnas. Keberadaan projek pembangunan perumnas di wilayah Depok memberikan implikasi bagi kedua belah pihak, bagi kota Jakarta menjadi jalan keluar sementara dari tekanan kebutuhan pemukiman penduduk. Sementara itu, keberadaan projek pembangunan perumnas berimplikasi terhadap semakin berkurangnya ruang bagi penduduk kota Depok untuk memproduksi kegiatan ekonomi agrarisnya.

Persoalan pemekaran dan perkembangan kota merupakan satu bagian dalam tema sejarah sosial yang cukup menarik untuk dipahami lebih mendalam. Dengan menempatkan persoalan pemukiman penduduk dalam fokus pembahasan mengenai kajian sejarah kota, usaha untuk memahami dinamika perkembangan kota, dengan beragam kompleksitasnya, diharapkan dapat memberikan perbendaharaan pengetahuan mengenai arah, tujuan, dan pola-pola perkembangan sebuah kota. 
Tulisan ini akan menempatkan kota Jakarta dan Depok sebagai fokus pembahasannya, dengan mempertimbang-kan dua kota ini disatukan oleh kedekatan aspek geografis dan historis. Secara geografis, kota Jakarta bersebelahan dengan kota Depok di wilayah Selatan, dan dalam konteks historis kota Jakarta (dahulu Batavia) memiliki sejarah yang dekat dengan kota Depok sejak masa penguasaan kongsi dagang VOC. Pertimbangan periode 1960-an hingga akhir 1990an, menjadi landasan temporal dalam tulisan sejarah ini. Pada 1960-an merupakan awal bagi pertumbuhan sosial dan ekonomi kota Jakarta (sejak akhir era pemerintahan Orde Lama), dan akhir 1990-an merupakan masa-masa ekspansi secara besar-besaran kedatangan penduduk kota Jakarta untuk bermukim di wilayah kota Depok.

Perhatian ilmu sejarah terhadap keberadaan kota beserta fenomenanya sudah berlangsung sejak cukup banyak lahirnya karya-karya sejarah yang membahasa mengenai sejarah kota. Sebagai generasi pertama dari karya sejarah yang membahas mengenai persoalan kota.

Menurut Kuntowijoyo sejak pemerintahan kolonial menguasai kota-kota di sebagian besar wilayah Hindia-Belanda, pertumbuhan kehidupan sosial dan ekonomi semakin berlangsung secara pesat. Hal ini ditandai dengan semakin banyaknya nilai-nilai modernisasi dan pertumbuhan infrastruktur di wilayah kota. Semenjak terjadinya perubahan sosial dan ekonomi yang semakin cepat di wilayah perkotaan, menurut Kuntowijoyo lebih lanjut menyatakan bahwa kota merupakan tempat bagi kaum terpelajar dan kelas menengah bernaung (Kuntowijoyo, 2003: 59-60). Pergerakan-pergerakan sosial yang terjadi diwilayah kota, secara umum banyak dipengaruhi dan dilakukan oleh dua kelompok sosial tersebut. Dengan kehadiran wilayah kota sebagai kelanjutan (sebelumnya wilayah desa) dari kegiatan sosial dan ekonomis pada masa kolonial, berpindahlah medan pergesekan sosial antara kekuatan kolonial-kapitalisme menghadapi masyarakat pribumi yang tertindas.

Sementara itu, karya sejarah yang fokus membahas mengenai sejarah kota dan di dalamnya terdapat elemen (konflik) pemukiman penduduk, disusun oleh Purnawan Basundoro, Dalam disertasinya yang menuliskan sejarah kota Surabaya sejak masa kolonial hingga setelah kemerdekaan. Karya sejarah yang berjudul perebutan ruang publik di kota Surabaya dari tahun 1900 hingga tahun 1960-an, memberikan penjelasan tentang bagaimana penguasa (dalam hal ini lembaga pemerintahan) menyusun dan mengelola ruang publik kota. Ruang publik kota sebagai spasial yang dimiliki dan di bawah naungan pemerintahan kota setempat menjadi wilayah yang cukup penting, karena selain sebagai pusat kegiatan sosial, keberadaan ruang publik juga dapat menjadi pusat dari kegiatan ekonomi masyarakat. Keberadaan jalan yang ada dan menghubungkan hampir seluruh wilayah kota, memberikan dampak berupa kemunculan pusatpusat kegiatan ekonomi dan bisnis di kota.

Para warga yang berada di kota, baik yang berasal dari kalangan menengah ke atas hingga masyarakat yang lemah dalam kehidupan ekonomi, bercampur dan saling bergesekan untuk saling dapat meraih manfaat serta keuntungan dari keberadaan ruang publik. Beberapa ruang publik yang menjadi arena perebutan antara pemerintah, pengusaha dan masyarakat kecil pribumi menurut Punawan Basundoro di antaranya ialah jalan raya, taman kota, tanah kosong yang belum terkelola, hingga wilayah pemakaman umum. Pada ruang-ruang publik tersebut, terjadi pertikaian dan pergesekan antara pemerintah, pengusaha (kepentingan industri) di satu pihak dengan masyarakat pribumi dipihak lain yang hendak mempertahankan keberadaannya dari peminggiran sosial-ekonomi di pihak lain

\section{METODE}

Penulisan artikel ini menggunakan metode sejarah dengan melakukan tahapan heuristik, kritik, interpretasi, dan historiografi (Gottschalk, 1985:57) melalui kajian Pustaka yang berhubungan erat dengan Materi Pembahasan. 
Heuristik adalah metode untuk mencari, mengidentifikasikan dan menemukan sumbersumber Sejarah. Pencaharian ini dilakukan bahwa sumber sejarah merupakan jejak-jejak yang masih dapat diperoleh untuk menelusuri kembali sebuah kejadian sejarah. Sejarah sebagai kejadian tidak dapat dimunculkan kembali, tetapi sejarah sebagai kisah/cerita dari kejadian yang dimaksudkan dapat direkonstruksi melalui jejak yang ditinggalkannya. Sumber sejarah dibagi dua berdasar bentuknya Sumber tertulis dan tidak tertulis. Sumber tertulis berupa dokumendokumen, prasasti, catatan perjalanan. Sumber tidak tertulis adalah sumber lisan yaitu pelaku yang terlibat dalam sebuah peristiwa sejarah.

Tahap Kritik merupakan tahap berikutnya setelah heuristik. Tahap kritik ini menjadi tahap seleksi terhadap sumber-sumber tersebut untuk menilai tingkat validitasnya. Tingkat validitas disini adalah otientifikasi (keaslian) sumber, kualifikasi data dalam sumber, dan originalitas sumber serta data dalam sumber.

Dari tahap kritik lalu menuju tahap interpretasi. Dalam tahap ini dilakukan penafsiran terhadap data yang telah terseleksi, melalui analisis dan sintesis. Analisis adalah menguraikan sekian data yang ada dan kemudian mencari hubungan dari data-data tersebut melalui sintesis. Untuk mengontrol tingkat objektifitas penafsiran maka digunakan teori serta konsep ilmu-ilmu sosial sehingga hasil penafsiran tidak terjebak dalam sudut pandang subjektif melainkan sebesar-besarnya kepada objektifitas (Kartodirdjo, 1992:24).

Terakhir adalah Historiografi yaitu mengaktualisasikan hasil penafsiran ke dalam bentuk tulisan. Dalam historiografi diharapkan adanya aspek seni didalam membahasakan hasil penafsiran tersebut. Aspek seni disini tidak dimaksudkan untuk membawa penafsiran/eksplanasi menjadi subjektif atau sekedar bercerita saja tetapi memberi nilai art, karakter, sehingga tulisan sejarah menjadi tulisan yang hidup, tidak kering, karena keberhasilan sebuah historiografie modern di tandai dari kemampuan tulisan itu menghidupkan kembali suatu kejadian sejarah tanpa meninggalkan aspek kritis dan objektifitasnya (Kuntowijoyo, 2004:35).

\section{PEMBAHASAN}

\section{Persoalan Kependudukan Kota Jakarta dan Depok Periode 1970-an}

Pasca keruntuhan pemerintahan Presiden Soekarno di pertengahan 1960-an, Indonesia banyak melakukan langkah-langkah perbaikan kehidupan nasional. Melalui pemerintahan yang dipimpin oleh Presiden Soeharto, langkah utama yang dilakukan untuk menstabilkan kehidupan nasional, adalah dengan memperbaiki kehidupan ekonomi nasional. Dinamika politik nasional yang sebelumnya begitu mendominasi dalam periode pemerintahan Presiden Soekarno, pada masa pemerintahan Presiden Soeharto mulai dikendalikan dan langkah-langkah perbaikan kehidupan ekonomi menjadi pilihan prioritas untuk mengendalikan gejolak dalam ranah politik (Husin dan Taufik, 2018: 29).

Berbekal konsep dan teori ekonomi barat mengenai perwujudan negara kesejahteraan, pemerintahan Presiden Soeharto mencoba menerapkan sistem ekonomi barat yang ditopang oleh para sarjana Indonesia lulusan universitas dari Amerika Serikat. Kontrol terhadap dinamika kehidupan sosial-politik dan ekonomi nasional dijalankan dari kota Jakarta, kota ini kemudian semakin menegaskan sebagai kota peninggalan kolonial yang modern, disusun dengan ide-ide dan konsep-konsep barat (Husin dan Taufik, 2018: 30). Pembangunan infrastruktur kota dalam bentuk keberadaan gedung-gedung pemerintahan dan sektor swasta menjadi sesuatu yang membedakan antara kota Jakarta, dengan kota-kota lainnya di Indonesia.

Pada periode 1970-an seiring dengan peningkatan infrastruktur kota, kota Jakarta mulai kedatangan para kaum urban yang mencoba mengadu nasib untuk dapat bertahan hidup ataupun meningkatkan taraf kehidupannya. Kegiatan ekonomi kota Jakarta menjadi semacam magnet bagi kaum urban untuk mendapatkan pekerjaan, dan meraih pendapatan dari sektor jasa. 
Berdasarkan sumber yang dituliskan oleh Ali Sadikin dalam memori kepemimpinannya di Jakarta (Pidato Ali Sadikin dalam Tri Wahyu Ningsih Irsyam, 2017: 113), pada akhir kepemimpinannya jumlah penduduk kota Jakarta semakin bertambah seiring dengan laju kedatangan para kaum urban. Jumlah penduduk di kota Jakarta pada masa kepemimpinan Gubernur Ali Sadikin pada awal pengangkatannya adalah 3.639.465 jiwa, pada akhir periode kepemimpinan pertama (1972) mencapai 4.755.279 jiwa dan diakhir kepemimpinan kedua mencapai angka 5.925.417 jiwa (Irsyam, 2017: 116).

Peningkatan jumlah penduduk kota Jakarta sejak masa kepemimpinan Gubernur Ali Sadikin, merupakan konsekuensi logis akibat pembangunan yang berjalan dan perputaran roda ekonomi kota Jakarta yang lebih cepat dibandingkan dengan kota-kota lainnya di Indonesia. Keberadaan penduduk sebelumnya yang meningkat melalui angka kelahiran, serta ditambah dengan kedatangan para kaum urban yang semakin melonjak, memberikan implikasi terhadap kebutuhan hidup, seperti makan, kesehatan, perumahan, pekerjaan dan sebagainya. Rumah sebagai kebutuhan hidup manusia yang cukup penting (dalam posisi kebutuhan hidup primer), menjadi kebutuhan yang cukup mendesak bagi keberadaan para penduduk kota Jakarta, termasuk para kaum urban yang datang (Murray, 1994: 22).

Menghadapi persoalan dan kebutuhan pemukiman penduduk bagi masyarakat kota Jakarta, pemerintah pusat maupun pemerintah Daerah Khusus Ibu Kota Jakarta menjalankan dua kebijakan yang dianggap mampu meredam kedatangan kaum urban.

Langkah pertama yang dilakukan adalah dengan memulangkan kembali kaum urban yang datang ke Jakarta, karena tidak memiliki Kartu Tanda Penduduk (KTP) sebagai warga kota Jakarta. Kebijakan administrasi ini dilakukan untuk memfiltrasi keberadaan kaum urban yang hendak menetap di kota Jakarta. Langkah ini sejatinya dapat dikatakan kurang sukses dan berhasil dalam pelaksanaannya, karena operasi yustisia ini sering kali disiasati oleh para kaum urban dengan membuat Kartu Tanda Penduduk secara ilegal. Tri Wahyuning Irsyam (2017: 116) menjelaskan bahwa operasi pengecekan administrasi (KTP) kependudukan yang dijalankan oleh pemerintahan kota Jakarta tidak mampu untuk membendung para pendatang gelap yang masuk ke dalam kota Jakarta. Operasi yustisia yang berkaitan dengan kelengkapan administrasi kependudukan untuk masuk dan menetap di kota Jakarta, sampai hari ini tetap dilakukan oleh pemerintah DKI Jakarta, untuk membendung kedatangan kaum urban secara taktis (jangka pendek).

Kebijakan untuk menekan dan mengurai persoalan kependudukan di kota Jakarta yang semakin meningkat, selain dengan menjalankan kebijakan administratif kependudukan juga dijalankan kebijakan pembangunan pemukiman penduduk kota Jakarta. Seperti telah dikemukakan pada pendahuluan kota Jakarta memproyeksikan wilayah kota Depok, sebagai prioritas untuk wilayah pemukiman penduduk Jakarta. Persoalan pemukiman penduduk kota Jakarta sejatinya bukan hanya disebabkan oleh kedatangan kaum urban semata, akan tetapi juga berkaitan dengan model pembangunan kota Jakarta yang kerap kali membangun infrastruktur bangunan (gedung) untuk kebutuhan administrasi pemerintahan dan perkantoran swasta.

Pendirian bangunan-bangunan untuk kebutuhan pemerintahan dan sektor swasta berpadu padan dengan pembangunan sentra kegiatan ekonomi (pasar dan mall), sentra kesehatan masayarakat (rumah sakit, puskemas, klinik dan sebagainya), sentra kegiatan ibadah (masjid, gereja dan lainnya), sentra kebutuhan pendidikan (sekolah, kampus-kampus dan institusi kependidikan lainnya), serta kebutuhan masyarakat lainnya yang termanifestasi dalam keberadaan bangunan-bangun untuk kebutuhan publik (Sulistyani, 2002: 328).

Pemanfaatan ruang (ekologi) kota Jakarta yang diarahkan untuk kepentingan publik (kebutuhan sosial dan ekonomi), memberikan implikasi berupa penataan ruang kota yang berorientasi kepentingan publik. Belum lagi kemajuan dalam bidang ekonomi yang kerap kali menuntut pembukaan lahan dan pengalihan fungsi lahan di Jakarta untuk kepentingan ekonomi. Pengalihan fungsi lahan di kota Jakarta yang berorientasi terhadap kepentingan 
ekonomi,merupakan bagian yang inheren dan selaras dengan kebijakan pemerintah pusat yang cenderung ramah terhadap kepentingan modal dan bisnis. Terhitung sejak periode 1980-an, cukup banyak terjadi fenomena pengalihan fungsi lahan dari lokasi pemukiman penduduk menjadi pembangunan sentra kegiatan ekonomi (seperti mall dan pusat-pusat perbelanjaan lainnya).

Bergesernya keberadaan fungsi-fungsi lahan pemukiman penduduk untuk kepentingan yang bersifat ekonomi, merupakan konsekuensi logis dari meningkatnya taraf kehidupan ekonomi warga kota Jakarta di periode pertegahan 1970-an. Naiknya harga minyak dunia (boom minyak) pada 1980-an memberikan suntikan pendanaan bagi pemerintah pusat untuk memberikan fasilitas terbaik bagi warga kota Jakarta (Booth dan Mc Cawley, 1982: 235).

Menjelang ahkir 1980-an melalui keuntungan finansial yang didapat oleh pemerintah melalui eksport minyak bumi dan hasil tambang lainnya, pemerintah banyak mendirikan lembaga pendidikan dan sarana kesehatan untuk dapat semakin mensuporting kepentingan ekonomi nasional. Sentra-sentra kependidikan dan kesehatan yang dibangun oleh pemerintah pusat, cukup banyak dibangun dan dikelola di kota Jakarta.

Menghadapi persoalan keberadaan ruang untuk pemenuhan kebutuhan pemukiman yang semakin hari, semakin meningkat bagi penduduk kota Jakarta, diputuskan oleh pemerintah pusat untuk membangun projek pembangunan pemukiman penduduk di wilayah-wilayah yang berbatasan dengan kota Jakarta. Depok, Bekasi, dan Tanggerang (selatan) adalah wilayahwilayah yang diprioritaskan untuk pembangunan pemukiman penduduk bagi masyarakat kota Jakarta, yang tidak mampu membeli lahan tinggal di sekitar wilayah Jakarta (Sulistyani, 2002: 329-330; Kasim dan Suhendar dalam Noer Fauzi, 1997: 97).

\section{Rumah Perumnas Versus Rumah Penduduk Lokal (Non-Perumnas)}

Pemenuhan kebutuhan pemukiman penduduk bagi warga kota Jakarta, sejatinya bukan sebuah persoalan yang tidak dicari jalan keluarnya oleh pemerintah DKI Jakarta selama periode 1980-an, hingga awal 1990-an. Pemerintah DKI Jakarta pernah melakukan terobosan dengan membangun konsep rumah susun sebagai rumah tinggal, akan tetapi dalam perjalanannya keberadaan rumah susun sebagai rumah tinggal tidak mampu memenuhi kebutuhan persoalan kebutuhan pemukiman penduduk. Di tengah berbagai kekurangan seperti jumlah yang terbatas, minim fasilitas dan kualitas bangunan yang belum memadai untuk mencapai taraf rumah tinggal yang ideal, menjadi beragam persoalan bagi upaya pemenuhan kebutuhan pemukiman penduduk kota Jakarta. Secara psikologis juga mungkin mempengaruhi bagi penduduk kota Jakarta untuk bermukim di pemukiman rumah susun, karena tipikal masyarakat Indonesia merupakan tipikal masyarakat yang memiliki habit bermukim di atas tanah (menjejakan kaki) di darat, tentu hal ini akan menjadi problematika tersendiri bagi ranah psikologis masyarakat Jakarta yang bermukim di rumah susun.

Pemenuhan kebutuhan pembangunan rumah tinggal bagi penduduk Jakarta, juga dilakukan oleh sektor swasta di Jakarta. Ketidakmampuan pemerintah dalam memberikan rumah tinggal dengan indikator layak huni, kemudian diberikan kepada sektor swasta. Biaya cost produksi yang cukup tinggi dalam membangun perumahan tinggal di kota Jakarta, karena kurangnya ketersediaan lahan bagi pemukiman (lebih menguntungkan membangun gedung bagi sarana perkantoran dan perbelanjaan) yang membuat harga jual tanah dan bangunan yang didirikan di atasnya menjadi lebih tinggi. Tingginya harga jual tanah dan bangunan untuk pemukiman tinggal masyarakat di Jakarta, membuat tidak banyak warga Jakarta yang mampu memiliki hunian/rumah tinggal. Pada faktanya, masyarakat Jakarta merupakan didominasi oleh kelompok sosial yang hidup dan memiliki keterampilan rendah, hal ini memberikan implikasi berupa tingkat pendapatan yang rendah (Silistyani, 2002: 329).

Kebijakan pemerintah pusat untuk membantu pemerintah DKI Jakarta, untuk memenuhi kebutuhan pemukiman rumah tinggal dijalankan dengan membangun rumah tinggal bagi 
penduduk Jakarta di sekitar daerah perbatasan dengan kota Jakarta. Depok sebagai kota yang berbatasan langsung dengan kota Jakarta, menjadi pilihan untuk dibangun pemukiman rumah tinggal untuk masyarakat Jakarta. Pada pertengahan 1970-an, pemerintah pusat menjalankan pelaksanaan projek pembangunan rumah tinggal bagi masyarakat kota Jakarta di wilayahwilayah yang berbatasan kota Jakarta. Proyek ini umumnya dikenal dengan nama pembangunan Perumahan Nasional (Perumnas), dibawah operasional Perusahaan Umum (Perum) Perumahan Nasional, dan pertama kali dibangun di wilayah Depok dan Bekasi (Cahyadi dan Surtiari, 2009: 56; Irsyam, 2017: 134).

Kota Depok dipilih oleh pemerintah pusat sebagai area untuk membagi beban kependudukan yang berlangsung di kota Jakarta dengan beberapa pertimbangan, di antaranya ialah keberadaan sarana dan prasarana transportasi serta perbandingan jumlah penduduk setempat dengan luas wilayah yang dimiliki. Sarana transportasi yang menghubungkan antara kota Jakarta dan Depok terbagi atas dua jenis moda transportasi, yakni kendaraan bermotor yang dapat melintas di sepanjang jalan raya Bogor, serta jalan raya yang berada di wilayah Margonda (Irsyam, 2017: 134-135).

Selain moda transportasi jalan raya, jaringan layanan transportasi kereta juga sudah menghubungkan antara kota Jakarta, Depok dan kota Bogor. Sarana transportasi tersebut, sejatinya sudah menghubungkan kedua kota (Jakarta dan Depok) sejak masa kolonial. Sementara itu melalui pertimbangan luas wilayah dan jumlah kepadatan penduduk, sebelum dibangun perumnas, kota depok memiliki luas wilayah sebesar 6.794 .902 hektar, dengan jumlah penduduk sebesar 77.915 jiwa. Pemerintah pusat memiliki pengharapan agar kemudian kota Depok setidaknya mampu menampung jumlah penduduk kota Jakarta sebesar 182.000 jiwa setelah perumnas dibangun (Irsyam, 2017: 135, 141).

Pembangunan perumnas oleh pemerintah pusat sejatinya diorientasikan untuk para pegawai negeri di instasi pemerintah, serta karyawan yang bekerja di Badan Usaha Milik Negara. Para pegawai negeri dan karyawan yang bekerja di badan usaha milik negara, diberikan rumah tinggal yang biayanya diambil dari potongan gaji/pendapatan setiap bulannya. Kebijakan ini dilakukan untuk mempermudah para pegawai negeri dan karyawan (BUMN) untuk memiliki rumah tinggal (Wawancara dengan Subroto pada 12 Agustus 2018).

Selain difasilitasi cara pembayaran yang mudah, para pegawai dan karyawan di bawah naungan pemerintahan juga diberikan fasilitas sarana berupa kendaraan jemput untuk bekerja dari kota Depok menuju kota Jakarta, cara ini dilakukan agar banyak pegawai negeri dan karyawan (BUMN) mengikuti dan mensukseskan kebijakan pemukiman tinggal di perumnas. Pembangunan perumnas di kota Depok pertama kali di bangun di wilayah Beji Depok, selanjutnya dibangun diwilayah Sukmajaya Depok II Tengah seluas 117 hektar dan Depok Timur seluas 170 hektar (Poestahadepok.blogspot.com,2012).

Berdirinya perumnas di kota Depok yang bersumber dari pengalihan lahan pertanian dan perkebunan milik masyarakat memberikan implikasi terhadap kegiatan mata pencaharian bagi warga kota Depok. Sistem mata pencaharian yang pada awalnya berbasiskan kepada kegiatan pertanian dan perkebunan, perlahan-lahan bergeser menjadi sistem mata pencaharian yang bersumber pada sektor jasa (Irsyam, 2017: 134). Perlahan-lahan setelah perumnas dihuni, pada awal periode 1980-an, jumlah penduduk kota Depok meningkat menjadi 215.577 jiwa. Keadaan ini kemudian mendorong pembangunan sarana dan prasarana berupa pranata pendidikan (SMP dan SMA), kesehatan (puskesmas dan rumah sakit), serta fasilitas publik lainnya (Irsyam, 2017: $136,140)$.

Kehadiran masyarakat pendantang yang berasal dari kota Jakarta, memberikan dampak yang cukup besar bagi perkembangan kehidupan sosial dan ekonomi di kota Depok. Ranah kehidupan masyarakat yang cukup berpengaruh adalah sektor atau kegiatan ekonomi masyarakat, jika sebelumnya masyarakat kota Depok menekankan kepada sektor pertanian dan perkebunan dalam sistem mata pencahariannya. Kehadiran para pendatang yang berasal dari 
kota Jakarta, telah membuat peluang untuk mempertahankan sistem mata pencaharian melalui pertanian dan perkebunan menjadi berkurang, seiring perubahan fungsi lahan menjadi tempat tinggal. Sementara itu, di sisi lain kehadiran para pendatang yang berasal dari kota Jakarta, yang cenderung berwatak konsumtif, memberikan kesempatan bagi kemunculan pranata-pranata ekonomi dari yang bermodal kecil, seperti warung dan toko kelontong hingga yang bermodal besar, seperti mall dan departmen store (Irsyam, 2017: 154).

Sektor jasa dan perdagangan kemudian mendapat kesempatan untuk semakin tumbuh dan berkembang di kota Depok, seiring dengan peningkatan jumlah kaum urban dan pemenuhan kebutuhan hidup para kaum pendatang. Salah satu sektor jasa yang semakin berkembang di kota Depok memasuki periode tahun 1990-an, adalah jasa sewa tempat tinggal (rumah sewa), hal ini dapat terjadi karena para pendatang yang hadir di kota Depok semakin banyak jumlahnya dan semakin variatif dalam tingkat kekuatan ekonomi. Jumlah pendatang yang semakin besar ke dalam kota Depok, sejatinya memberikan dorongan bagi kebutuhan yang utama lainnya, yakni kebutuhan makanan sehari-hari.

Dalam memenuhi kebutuhan pokok sehari-hari, warga kota Depok mendapatkannya melalui suplai kebutuhan makanan melalui produksi yang berasal dari wilayah Bogor. Para pedagang di kota Depok membangun satu jaringan ekonomi yang menautkan antara kota Depok dengan wilayah Bogor dalam mendapatkan suplai beras, sayur-mayur, daging, ikan dan sebagainya. Jaringan dagang ini umumnya dibentuk dengan mengirimkan anggota keluarga yang berasal dari wilayah asal (Jawa Barat, Tangerang hingga luar Jawa), untuk menetap dan tinggal. Kemudian mendapatkan distribusi dari para kolega yang berada di wilayah luar untuk memasok dan memperdagangkan kebutuhan makanan pokok sehari-hari (Wawancara dengan Bapak Hasan pada 24 Agustus 2018).

Perilaku jaringan dagang tersebut, umumnya berlangsung dan terbentuk pada periode 1990-an, pada saat bank-bank swasta dan pemerintahan belum banyak mengucurkan pendanaan untuk modal usaha. Bentuk jaringan ekonomi tradisional yang bertumpu pada kemampuan modal primordial dan keluarga menjadi jaringan ekonomi awal yang membangun kehidupan ekonomi kota Depok dalam konteks pemenuhan kebutuhan pangan. Bentuk jaringan ekonomi tersebut (ekonomi primordial dan kekeluargaan) membuka kesempatan untuk bertahan dan bermukim di kota Depok, maka dari itu kebutuhan perumahan tinggal di sekitar sentra kegiatan dagang (pasar) cukup banyak bermunculan di kota Depok. Rumah sewa yang disediakan oleh para pemilik tanah lokal di kota Depok, semakin banyak bertumbuh, seiring banyaknya permintaan akan tempat tinggal yang murah dan terjangkau dengan aktivitas ekonomi seharihari (Wawancara dengan Simanjuntak pada 29 Juli 2018).

Pada periode awal 1990-an ini juga menjadi penanda semakin banyaknya masyarakat kota Jakarta yang bermigrasi ke wilayah kota Depok. Bukan hanya masyarakat yang berkemampuan ekonomi kecil dan menengah, beberapa anggota keluarga yang berasal dari keluarga elite dan pejabat pemerintahan (DKI Jakarta) dan pemerintah pusat bermigrasi dari kota Jakarta menuju kota Depok. Kota Depok yang masih memberikan gambaran sebagai wilayah yang asri dan sejuk karena masih banyak pepohonan, menjadi daya tarik bagi masyarakat elite kota Jakarta yang hendak meninggalkan suasana kepenatan di ibu kota Jakarta, yang semakin tinggi. Selain itu, terdapat motif lainnya yang membuat warga elite kota Jakarta untuk berpindah ke kota Depok, harga beli tanah dan tempat tinggal di kota Depok cukup rendah dibandingkan dengan harga beli tanah dan tempat tinggal di kota Jakarta (Wawancara dengan Subroto pada 12 Agustus 2018).

Tanah dan tempat tinggal di kota Depok dapat menjadi investasi bagi para elite masyarakat kota Jakarta. Keberadaan sarana transportasi yang semakin lama semakin meningkat, jalan beserta moda transportasi yang menghubungkan kota Depok dengan kota Jakarta, juga menjadi alasan lain bagi goolongan masyarakat tingkat atas kota Jakarta untuk mau bermigrasi ke kota Depok di periode 1990-an (Irsyam, 2017: 155). 
Kehadiran para golongan masyarakat Jakarta berkemampuan ekonomi tinggi, menjadi salah satu alasan sektor properti swasta untuk menawarkan rumah hunian yang bernuansa modernis, beradab dan berbeda dengan rumah hunian lainnya di kota Depok. Pada periode pertengahan 1990-an, cukup banyak kelompok bisnis properti sektor swasta yang berlombalomba menawarkan dan membangun rumah-rumah dengan kategori mewah, asri dan nyaman di kota Depok. Beberapa di antaranya yang masuk ke dalam golongan perumahan elite dan dibangun oleh sektor swasta adalah perumahan Griya Asri Depok, dan Pondok Sukmajaya Depok.

\section{Perkembangan di Akhir 1990-an (Keberadaan UI dan Kampus Swasta)}

Memasuki periode akhir 1990-an, sudah mulai kesulitan untuk dapat membedakan apakah kota Depok masih menjadi bagian dari wilayah Jawa Barat jika menilik perubahan sosial dan ekonomi yang berlangsung di dalamnya. Pola hubungan sosial yang hidup melalui sistem ekonomi pertanian dan perkebunan cenderung semakin menghilang, dan berganti menuju hubungan ekonomi bertipe industri (jasa) dan perdagangan, memberikan gambaran kepada kita bahwa kota Depok bagaikan imitasi atau menyerupai dengan model kehidupan di kota Jakarta.

Aspek modernitas semakin mengeser keberadaan nilai-nilai tradisional kota Depok, manakala simbol-simbol modernisasi dalam bentuk perguruan tinggi muncul di kota Depok (baik perguruan tinggi negeri maupun swasta). Berdirinya Universitas Indonesia di awal 1990an, serta keberadaan perguruan tinggi swasta, seperti Universitas Gunadarma di kawasan Margonda, memberikan kesan bahwa kota Depok siap menyongsong sisi kehidupan yang lebih modernis.

Keberadan perguruan tinggi tersebut semakin mempercepat perubahan sosial di kota Depok, dengan kehadiran para pendatang yang berasal dari luar kota Depok untuk melanjutkan studi (hingga para pendatang yang berasal dari luar pulau Jawa). Perguruan tinggi, seperti Universitas Indonesia dan Universitas Gunadarma, yang berorientasi terhadap ilmu pengetahuan dan teknologi, memberikan kesempatan bagi warga kota Depok bersinggungan dengan teknologi-teknologi modern. Menuju akhir 1990-an, warga Depok yang tinggal di sekitar jalan Margonda, sudah terbiasa dengan kehadiran mesin fotocopy, warung telekomunikasi (wartel), komputer, dan internet. Kehadiran teknologi-teknologi modern tersebut memberikan dampak terhadap masyarakat kota Depok yang menggunakannya (Irsyam, 2017: 154).

Kehadiran teknologi modern di sekitar lingkungan perguruan tinggi (UI dan Univ. Gunadarma di jalan Margonda), menjadi nilai tambah untuk semakin menghadirkan para pendatang yang hendak melanjutkan studi di kota Depok (memberikan kemudahan dalam proses studi dalam mengerjakan tugas-tugas perkuliahan). Kedatangan para mahasiswa yang berasal dari luar kota Depok, memberikan peluang bagi munculnya bisnis penyewaan tempat tinggal (sewa ruang kost) di sekitar wilayah pemukiman penduduk di jalan Margonda. Bagi para pemilik rumah dan lahan yang belum dibangun, membuka usaha penyewaan tempat tinggal (kost) merupakan usaha yang cukup menguntungkan. Cukup banyak rumah-rumah tinggal yang kemudian berubah dan direnovasi untuk dijadikan rumah kost, bahkan cukup banyak pula tanah-tanah yang sebelumnya tidak produktif kemudian dibangun menjadi rumah sewa hingga bangunan kost (Wawancara dengan Sutardjo pada 02 September 2018).

Seperti yang diungkapkan oleh Sutardjo, pada periode pertengahan 1990-an, orang tuanya memasuki masa pensiun sebagai karyawan swasta, dan beralih menjadi pemilik sewa tempat tinggal di Jl. Kober (Margonda) untuk para mahasiswa.Rumah yang berbentuk dua tingkat tersebut, setelah direnovasi, menghasil 6 ruang kamar untuk para penyewa kost. Dari masingmasing kamar orang tua Sutardjo mendapatkan Rp. 50.000; dan masing-masing ruangan diberikan fasilitas berupa kasur lantai dan sebuah lemari kecil. Melalui usaha sewa tempat tinggal kost tersebut, keluarga Sutardjo mampu membeli (dengan sistem kredit) rumah tinggal di Perumahan Pondok Sukmajaya Depok yang dibangun oleh pengembang swasta. Hingga saat 
ini Sutardjo mewarisi usaha rumah sewa (kost) dari kedua orang tuanya, dan pendapatan dari setiap kamar sebesar Rp. 1.800.000; dengan fasilitas single bed, lemari pakaian minimalis dan 1 pendingin ruangan $(\mathrm{AC})$.

Kehadiran para pendatang yang bermukim di sekitar lingkungan perguruan tinggi di jalan Margonda Depok, membuat para pemilik rumah tinggal menjadikan rumah bahkan hingga lahannya untuk usaha sewa tempat tinggal, warung kebutuhan hidup sehari-hari, toko buku dan alat tulis, warung makan, usaha cuci dan menyetrika pakaian, dan sebagainya. Selain mendatangkan pemasukan bagi para pemilik usaha, kemunculan usaha tersebut juga membuka kesempatan lapangan pekerjaan sebagai pelayan warung, dan pelayan penyedia jasa usaha lainnya (Wawancara dengan Sutardjo pada 02 September 2018). Pada akhirnya keberadaan usaha yang dikelola berbentuk sederhana dan tradisional tersebut, memberikan pendapatan kepada pemerintah kota Depok.

\section{PENUTUP}

Kajian terhadap perkembangan kota beserta dengan segala persoalannya merupakan sebuah kajian yang cukup menarik, mengingat dalam siklus perkembangan kota tersebut, akan nampak perubahan-perubahan yang cukup signifikan. Seperti pembahasan mengenai pemukiman penduduk di kota Jakarta dan Depok ini, persoalan pemenuhan kebutuhan pemukiman dan tempat tinggal bagi para penduduk merupakan persoalan yang melibatkan cukup banyak hal. Kemajuan ekonomi di satu sisi dengan berimbas kepada kedatangan para kaum urban ke kota Jakarta, memberikan implikasi terhadap pengalihan fungsi ruang yang dioerientasikan kepada arah perkembangan laju ekonomi di kota Jakarta. Keberadaan gedunggedung dan bangunan-bangunan untuk kepentingan pemerintahan dan kegiatan bisnis (ekonomi), menggeser keberadaan pemukiman penduduk yang telah ada. Di sisi lain perluasan ruang-ruang baru bagi kepentingan sosial dan ekonomi menjadi tidak terhindarkan, sehingga kebutuhan field (arena) baru menjadi tidak terhindarkan.

Upaya untuk membuka arena baru membutuhkan kemampuan (power) yang sejatinya dimiliki oleh pemegang kekuasaan dalam hal ini pemerintah sebagai pemegang kekuasaan dapat memunculkan field (arena) yang baru, untuk kasus perkembangan pemukiman penduduk di kota Jakarta, kota Depok merupakan arena baru yang dibentuk oleh kekuasaan. Kemunculan kota Depok sebagai arena baru bagi kepentingan pemenuhan kebutuhan pemukiman penduduk (rumah tinggal), merupakan perluasan dari dinamika dan perkembangan kapital di kota Jakarta yang sudah tidak mampu lagi diakomodir di dalam arena kota Jakarta. Dalam narasi yang diberikan di tulisan ini, kota Depok menjadi arena tiga kepentingan yang saling bertemu, dan bekehendak menguasai dan mengelola arena baru tersebut (kota Depok). Tiga kepentingan tersebut di antaranya adalah pemerintah (berkepentingan untuk mengelola kota Depok sesuai dengan kepentingan negara), kepentingan pengusaha yang disarakan atas orientasi bisnis dan profit, serta kepentingan warga negara yang mencoba bertahan hidup dari himpitan dua kepentingan tersebut.

\section{DAFTAR RUJUKAN}

Booth, A \& Mc Cawley, P.(1982). Ekonomi Orde Baru. Jakarta: LP3ES.

Cahyadi, R. \& Sutiari, Gusti, A.K. Penduduk dan Pembangunan Perumahan di Jabodetabek: Tantangan Pengembangan Megapolitan Jakarta. Jurnal Kependudukan Indonesia. Vol. IV, No. 1, 2009.

Fauzi, N (Penyunting). (1997). Tanah dan Pembangunan. Jakarta: Sinar Harapan 


\section{Sosio e-kons}

Volume 11, No. 1, April 2019, pp. 55-65

e-ISSN: 2502-5449

p-ISSN: 2085-2266

DOI : 10.30998/sosioekons.v11i1.2877

Irsyam, T.W. (2017). Sejarah Depok 1950-1990an. Jakarta: Buku Obor.

Murray, A.J. (1994). Pedagang Jalanan dan Pelacur Jakarta: Sebuah Kajian Antropologi Sosial. Jakarta: LP3ES.

Pemerintah DKI Jakarta. (1977). Gita Jaya : Catatan H. Ali Sadikin Gubernur Kepala Daerah Khusus Ibu Kota Jakarta 1966-1977.

Sulistyani, A.T. (2002). Problema dan Kebijakan Perumahan di Perkotaan, Jurnal Ilmu Sosial dan Ilmu Politik. 5, (3).

Wawancara dengan Subroto pada 12 Agustus 2018.

Wawancara dengan Bapak Hasan pada 24 Agustus 2018.

Wawancara dengan Simanjuntak pada 29 Juli 2018.

Wawancara dengan Sutardjo pada 02 September 2018.

http://poestahadepok.blogspot.com/2012/08/perumnas-depok-perumahan-nasional.html?m=1;

diakses pada 10 September 2018, pukul 16.17 wib 